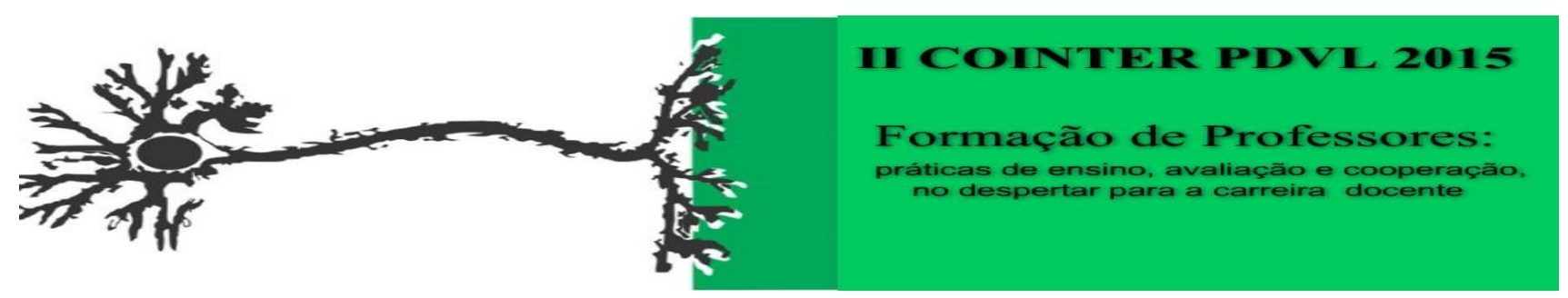

\title{
UM RELATO DE EXPERIÊNCIA PEDAGÓGICA SOBRE DILATAÇÃO TÉRMICA E VOLUMÉTRICA DOS GASES
}

\author{
Apresentação: Relato de Experiência \\ Matheus de Souza Carvalho ${ }^{1}$; Júlia Taisy do Vale Bezerra ${ }^{2}$; Marina Nunes de Oliveira ${ }^{3}$; \\ Albertina Marilia Alves Guedes ${ }^{4}$
}

\section{Introdução}

Para pesquisadores da área de Licenciatura em Física uma das estratégias pedagógicas que podem ser utilizadas por professores visando minimizar o índice reprovação na disciplina de Física é a realização de Experimentos Físicos. Para Araújo e Abid (2003), esse tipo de experimento pode despertar o interesse e curiosidade dos estudantes em aprender Física.

Para Fracalanza et al (1986) as atividades experimentais permitem aos alunos ter contato direto com o objeto de aprendizagem e, como consequência, podem compreender e aprender a importância dos conhecimentos sobre Física. Araújo e Abid (2003) ainda ressaltam que o uso de experimentos pode estimular a curiosidade do estudante em buscar respostas para os fenômenos físicos observados e, por sua vez, propiciar uma melhor compreensão dos conteúdos abordados.

\section{Relato de Experiência}

Essa experiência foi vivenciada no Laboratório de Ciências de uma escola pública na cidade de Petrolina-PE e teve a participação de 35 alunos do $2^{\circ}$ ano do Ensino Médio. As temáticas discutidas nesta experiência foram: dilatação térmica e volumétrica dos gases. Essa experiência foi considerada relevante visto que, apesar dos conteúdos de "dilatação térmica" e "volumétrica dos gases" estarem presentes no cotidiano dos alunos, percebe-se que os estudantes tem dificuldades em compreender e aprender sobre esses conteúdos.

Desse modo, o problema que norteou esse trabalho foi: Como é possível despertar o interesse e motivação de estudantes para a aprendizagem de conteúdos Físicos? Inicialmente foi apresentado aos alunos os principais conceitos e características de dilatação térmica e volumétrica

\footnotetext{
${ }^{1}$ Estudante do Curso de Licenciatura em Física do IF Sertão PE. E-mail: matheusds.carvalho@hotmail.com

${ }^{2}$ Estudante do Curso de Licenciatura em Física do IF Sertão PE. E-mail: julia_taisy@hotmail.com

${ }^{3}$ Estudante do Curso de Licenciatura em Física do IF Sertão PE. E-mail:marina.mno@hotmail.com

${ }^{4}$ Professora do Curso de Licenciatura em Física do IF Sertão PE. E-mail:albertinamarilia@hotmail.com
} 
dos gases. Os materiais utilizados nos experimentos foram: um becker, uma placa de petri, um erlenmeyer, tinta guache, fósforos, uma vela, uma garrafa de vidro e $400 \mathrm{ml}$ água fria e morna.

Objetivando verificar os conhecimentos prévios acerca do assunto abordado foram realizados alguns questionamentos aos alunos (AUSUBEL, 1968). Neste momento, foi possível saber o que os alunos compreendem sobre essas temáticas. Também foram apresentadas as principais características sobre "dilatação térmica e volumétrica dos gases". Em seguida, foi selecionado um experimento que abordava esse tema. Para a execução do experimento teve-se o cuidado em elaborar um planejamento prévio o qual descreveu cada etapa do experimento, bem como o objetivo almejado em cada etapa do planejamento.

Imagem 1: Atividade Experimental. Fonte: Própria

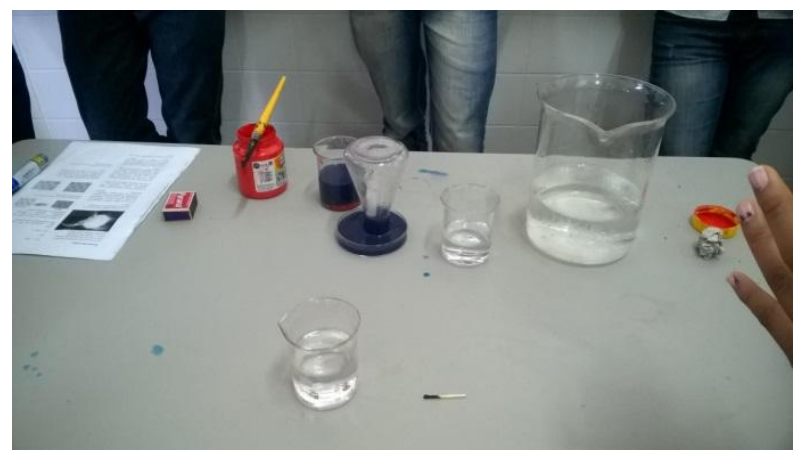

\section{Considerações}

A partir dessa experiência percebe-se que a realização de atividades experimentais em sala de aula podem facilitar a aprendizagem e despertar o interesse e curiosidade dos alunos sobre os conteúdos de Física mediante a realização de experimentos físicos. Possibilita também que a aula seja dinâmica e interativa mediante a manipulação dos objetos utilizados nos experimentos. Além disso, os alunos podem observar na prática como ocorre a dilatação de térmica e volumétrica de gases.

\section{Referências}

ABID, M. L; ARAÚJO, M. S. Atividades experimentais no ensino da Física: diferentes enfoques, diferentes finalidades. Revista Brasileira de Ensino de Física, v. 25, nº 2, p. 176-194, 2003.

AUSUBEL, D. P. Educational psychology: a cognitive view. Nueva York: Holt, 1968.

FRACALANZA, H. et al. O Ensino de Ciências no $1^{0}$ grau. São Paulo: Atual. 1986. 